\title{
Lovende effekt av ocrelizumab ved multippel sklerose
}

Ocrelizumab, et monoklonalt humant antistoff rettet mot CD20-positive B-celler, har effekt ved både anfallsvis og primær progredierende multippel sklerose. Dette viser tre nye studier.

B-celler kan påvirke patogenesen ved multippel sklerose. Tre studier der man undersøkte effekten av ocrelizumab mot henholdsvis anfallsvis og primær progredierende multippel sklerose er nylig publisert i tidsskriftet New England Journal of Medicine $(1,2)$.

I to fase 3-studier ble til sammen 1656 pasienter med anfallsvis multippel sklerose randomisert til behandling med $600 \mathrm{mg}$ ocrelizumab, gitt intravenøst hver 24. uke, eller $44 \mu \mathrm{g}$ interferon-beta-1a tre ganger ukentlig i 96 uker (1). Årlig tilbakefallsfrekvens var signifikant lavere med ocrelizumab enn med interferon-beta- $1 \mathrm{a}(0,16$ versus 0,$29 ; p<0,001 \mathrm{i}$ begge studiegrupper).

I studien av pasienter med primær progressiv multippel sklerose ble 732 pasienter randomisert til behandling med ocrelizumab 600 mg eller placebo intravenøst hver 24. uke i minst 120 uker og inntil et forhåndsdefinert antall hendelser forenlig med sykdomsprogresjon var registrert (2). Etter 12 uker hadde $32,9 \%$ i ocrelizumab-gruppen og 39,3\% i placebo-gruppen fått påvist sykdomsprogresjon (hasardratio 0,$76 ; 95 \% \mathrm{KI} 0,59-0,98$ ). I uke 120 hadde ocrelizumab-gruppen 38,9\% dårligere resultat ved gangtest enn ved studiestart, mens placebogruppen hadde 55,1\% dårligere resultat $(\mathrm{p}=0,04)$.

- De to studiene ved anfallsvis multippel sklerose viser svært god effekt av ocrelizumab, sannsynligvis noe av det beste man har sett til nå, sier Trygve Holmøy, som er overlege ved nevrologisk avdeling, Akershus universitetssykehus, og professor ved Universitetet i Oslo.

- Antistoffet ocrelizumab ligner på rituksimab, som vi har mange års erfaring med.
Det er særlig spennende at ocrelizumab ser ut til å ha effekt også ved primær progressiv multippel sklerose, sannsynligvis fordi en del av disse pasientene har aktiv inflammasjon.

- Utfordringen fremover blir å bestemme hvilke pasienter med progressiv sykdom som bør tilbys slik behandling, og hvor tidlig den bør tilbys pasienter med anfallsvis multippel sklerose. Tidlig oppstart med effektive preparater kan forebygge hjerneskade. Det vil derfor være viktig med langtidsdata fra pasienter med nyoppstått multippel sklerose, ikke minst for å utelukke at vedvarende B-celledeplesjon fører til økt kreftrisiko, sier Holmøy.

\section{Kari Tveito}

Tidsskriftet

\section{Litteratur}

. Hauser SL, Bar-Or A, Comi G et al. Ocrelizumab versus interferon beta-1a in relapsing multiple sclerosis. N Engl J Med 2017; 376: 221 -34.

2. Montalban X, Hauser SL, Kappos L et al. Ocrelizumab versus Placebo in Primary Progressive Multiple Sclerosis. N Engl J Med 2017; 376: 209-20.

Publisert først på nett.

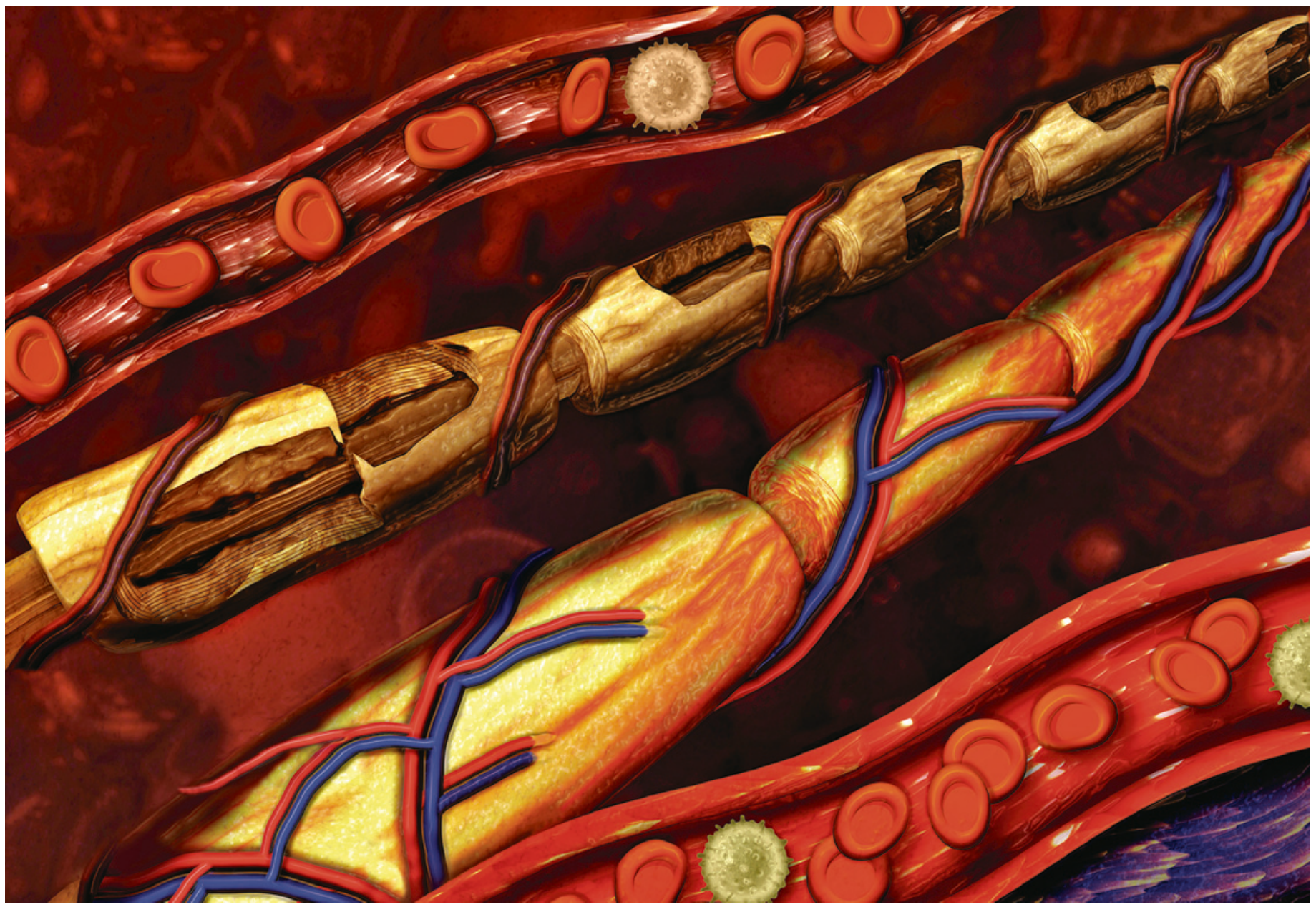

Normalt blodkar og nerve illustrert nederst til høyre; skadet blodkar og nerve vist øverst til venstre. Denne typen nerveskader kan oppstå ved multippel sklerose. Illustrasjon: Science Photo Library 